\title{
Governing together in good and bad times: the fulfilment of election pledges in Ireland
}

\section{Robert Thomson and Rory Costello}

\begin{abstract}
According to mandate theory, parties make pledges during election campaigns, and the parties that form governments after elections fulfil their pledges. We examine the extent to which the fulfilment of election pledges depends on the type of government that forms and the economic conditions governing parties face. We do this by examining the fulfilment of Irish parties' election pledges over a period of more than 30 years, 19772011. During the time period considered, the Irish electoral and party systems produced eleven governments of four distinct types: majority and minority coalitions as well as majority and minority single-party governments. The eleven governments that held office during this period also varied considerably from each other in duration and the economic conditions they faced. By examining variation in pledge fulfilment across these governments, are able to draw inferences about the effects of different types of government and economic conditions on pledge fulfilment.
\end{abstract}

According mandate theory and the responsible party model, the fulfilment of election pledges by governing parties is central to democratic representation, providing a mechanism by which citizens can exercise control over public policy (APSA 1950; Downs 1957; Klingemann et al. 1994). In this account, parties offer competing policy platforms to voters and 'the party which attracts the most votes on this basis then forms the next government, but it is bound (both morally and by fears of retribution at the next election) to carry through the program on which on which it has been elected' (Budge and Hofferbert 1990: 111). Mandate theory is closely associated with single-party governments, which implies the expectation that parties are more likely to fulfil their election pledges when they govern alone rather than in coalition (Klingemann et al. 1994: 31). However, extent to which a party in coalition government is able to fulfil its election pledges depends on a number of factors, such as the level of agreement with other government parties and whether it controls key positions within the government. Moreover, in certain circumstances (such as minority government) the ability of singleparty governments to fulfil their election pledges may be severely constrained.

This paper contributes to a growing body of research on pledge fulfilment (e.g. Pomper and Lederman 1980; Rallings 1987; Royed 1996; Thomson 2001; Artés and Bustos 2008; Naurin 2011; 2014; Kostadinova 2013). It does so by examining Ireland, which is of particular interest from a comparative perspective, not least because of the 
unique 34-year time period that our dataset covers, 1977-2011. The cases we examine enable us to study pledge fulfilment in four distinct types of governments within the same country context: single-party and coalition governments, both with and without legislative majorities. The eleven Irish governments that held office between 1977 and 2011 also varied considerably from each other with respect to the economic conditions they faced, including the boom years of the Celtic tiger as well as the bust following the 2008 financial crisis. By examining variation in pledge fulfilment across these eleven governments, we hold constant important features of the political culture, party system and electoral system that may account for some of the variation in pledge fulfilment in cross-national studies.

The next section gives a brief overview of the electoral and party systems of Ireland, as well as the eleven governments that held office during the time period considered. We then describe how we measure election pledges and their fulfilment. That section also reports the descriptive findings on the numbers of pledges and the percentages of those pledges that are fulfilled. The section after that turns to explanation, by outlining our expectations about the factors that influence the likelihood that pledges are fulfilled. We then proceed with the analyses and conclusions.

\section{Irish elections, parties and governments, 1977-2011}

Irish elections are conducted using the Single Transferable Vote (STV) system of proportional representation. This infrequently used system allows voters to choose candidates rather than parties in multi-seat constituencies. Voters rank the candidates in order of their preference, and a quota is calculated based on the number of votes cast divided by the number of seats in the constituency plus one. The consequences of this system include a high value placed on constituency work by elected representatives and the relatively large numbers of independent representatives, as well as coalition governments (Sinnott 2010).

We consider eight parties over the entire time period of the present study, although not all existed at the same time. These eight parties include all major parties according to a broad definition that includes all nationally organized parties that won at least two parliamentary seats. Six of these eight parties participated in government at 
some time during the 1977-2011 time period examined here. The main contenders for government office are Fianna Fáil and Fine Gael, the two largest parties, and the Labour Party, which is smaller. Either Fianna Fáil or Fine Gael has been in government throughout this period, but never together. Unlike the situation in most other European countries, these two main parties do not lie on opposite sides of the left-right divide. Their origins lie in differences over the national question in the early years after independence from the UK, rather than social or economic conflict, and both are essentially centre-right parties (Weeks 2010). The Irish Labour Party has always been much smaller than Social Democratic parties in other European countries; it typically receives 10 per cent of votes, with a particularly strong performance of 19 per cent of the votes in the 2011 election, after a major economic crisis.

In addition, three other parties have participated in government at various times. The Progressive Democrats (PDs) championed free market policies in Ireland. They held office as a junior coalition partner with Fianna Fáil in four governing periods considered here: 1989-92, 1997-2002, and 2002-07, and also joined the government that formed in 2007. After a decline in electoral support, the PDs began the process of disbanding in 2008, while its leader remained in government as an independent. The Democratic Left, which formed in 1992, held office together with Fine Gael and Labour, 1994-1997, before merging with the Labour Party in 1999. The Green Party's 1997, 2002 and 2007 manifestos are included in the present study. In 2007 the Greens participated in government office for the first time. Parties that were in opposition during the time period considered here are the Workers Party and Sinn Féin. The Workers Party was the predecessor to the Democratic Left. Sinn Féin's 2002 and 2007 manifestos are included in the present study. Sinn Féin has traditionally focused on the unification of Ireland and it also has strong socialist leanings.

The time period from 1977 onwards is a reasonable starting point for the analysis of election pledges because the 1977 Irish parliamentary election was a watershed in the development of comprehensive party platforms. Although both Labour and Fine Gael had been publishing manifestos for decades, 1977 was the first time that Fianna Fáil issued one. Fianna Fáil's conduct in the 1977 election campaign displayed a higher level of professionalism than in previous elections (Farrell and Manning 1978: 154). 
Table 1 summarizes the composition, duration and four types of governments examined in the present study. It is noteworthy that the three single-party governments included in our study are all Fianna Fáil governments. This means we cannot exclude the possibility that our findings with respect to the comparison of single-party and coalition governments are affected by the characteristics of this particular party. We therefore conduct an additional comparison of pledges made by Fianna Fáil when it entered single-party governments and coalition governments to examine whether this affects our findings. Moreover, not all minority governments are the same. Two of the four minority governments - Fianna Fáil 1982 and Fianna Fáil/PDs in 1997 - concluded agreements with independent parliamentarians, while the others did not. Again, we conduct an additional robustness test to examine whether this affects our findings. As noted above, the Irish system has a relatively high proportion of independent candidates. We do not examine the fulfilment of independents' election pledges, because they do not issue election manifestos that are comparable to those of national parties. Instead, independents generally focus more on local issues.

$<$ Table 1 $>$

Irish governments faced radically different economic conditions during the period examined here. Governments in the early 1980s managed an economy with sluggish growth and strained public sector finances. By contrast, governments in the late 1990s and early 2000s had managed a booming economy. Average economic growth reached its peak in the 1997-02 governing period at an average of 9.2 per cent each year. The 2007-11 period contains one of the most dramatic economic crises experienced by a Western government in recent decades. It revealed that Ireland's previous growth had coincided with an unsustainable property bubble and imprudent lending practices. The government initiated a massive bailout of Irish banks in 2008, amidst rising unemployment and soaring costs of government borrowing in international bond markets. This led to an international troika of the European Commission, the European Central Bank and the International Monetary Fund granting a bailout to the Irish exchequer in 2010 (Murphy 2011). Many observers concluded that the Irish government was effectively no longer in charge of running the country. The 
sitting coalition of Fianna Fáil and the Green Party fell, and both governing parties were punished severely by voters in February 2011, after which a new coalition consisting of Fine Gael and the Labour Party took office.

\section{Identifying election pledges and measuring fulfilment}

Most of the election pledges examined here are sourced from parties' manifestos. Although few voters actually read manifestos in detail, these documents contain the most definitive statements of the policies forwarded by parties during the campaign. There are two exceptions to this focus on manifestos where one of the parties did not publish a manifesto. The first exception is Fine Gael; it did not publish a manifesto in the February 1982 election. Instead, it fought the campaign on the basis of its recently defeated budget. Fine Gael's policy intentions were set out in a speech given in defence of that budget by the then Prime Minister (Taoiseach), Garret FitzGerald, to Galway Chamber of Commerce. This speech is used in place of a party manifesto. The second exception is that Fianna Fáil did not produce a manifesto for the November 1982 election. Here, the party leader wrote an article in the Irish Times just before the election, which other researchers have used as a substitute for the manifesto (for example in the Comparative Manifestos Project). However, this speech did not contain any testable pledges and so we exclude it from the analysis.

We include the election manifestos or equivalent documents published by all of the major parties prior to the election, regardless of whether they went on to participate in government after the election. There are two reasons for including the manifestos of opposition parties in the study. First, elections are supposed to be about choices between alternatives. We need to include the manifestos of all parties to identify the nature and extent of those choices. Second, mandate theory refers to a particular pattern of congruence between parties' election programmes and government policies; the level of congruence should be higher for governing than opposition parties. Perhaps surprisingly, election pledges made by parties that do not enter government after elections may be fulfilled. Although they do not hold power, opposition parties may also respond to the same underlying determinants of public policies, their pledges may 
agree with pledges made by parties that entered government, and governing parties may take popular proposals from the opposition.

We consider a statement to be a pledge if it contains 'unequivocal support for a specific action or outcome that is testable'. This definition follows the definition proposed by Royed (1996). In line with Thomson (2001), we add that for a statement to be a pledge, it must identify the "criteria on the basis of which we can examine whether the pledge is fulfilled'. Regarding the strength of 'unequivocal commitment' required, we include 'soft' commitments, such as 'we support' or 'we will strive toward', as well as 'hard' commitments, such as 'we will' or 'we promise to'.

With respect to the amount of detail required on the action or outcome, our definition of an election pledge requires that parties specify the criteria on the basis of which we can assess fulfilment. It is not enough for a party to refer to a policy problem and say it will do something about this problem. So the statement that "we will actively support the development of industry-based research capacity' (found in the Fianna Fáil manifesto of 2002) does not meet our definition. We argue that there are many different ways of increasing industry-based research capacity, including tax breaks for research and development in the private sector, subsidies for collaboration between universities and industry, as well as direct public funding of innovation in companies. Our choice of specific and directly testable statements is appropriate in the Irish context because parties are quite detailed when setting out their policy intentions, as will become clear in the next section.

Each manifesto was coded by a researcher who is familiar with the Irish political context. The researcher went through the manifesto line by line, marking the statements that met the definition of an election pledge. Similar pledges, or pledges that elaborated on a previous pledge (e.g. a pledge to reduce the basic rate of taxation followed by a pledge to reduce the basic rate of taxation to a specific percentage) were combined and counted as single pledges. As part of a series of reliability tests, seven researchers independently coded portions of a manifesto using this definition of election pledges. Each coder identified approximately 65 election pledges. The average paired reliability 
for the exercise was 76 per cent, with a range of 64 to 86 per cent (insert author reference). ${ }^{1}$

Irish parties make considerable numbers of election pledges. On average, each manifesto or equivalent includes 72.9 pledges $(n=45)^{2}$. Fianna Fáil, however, made only two pledges in February 1982 manifesto, and none in the newspaper article that other researchers have used as a substitute for its November 1982 manifesto. By contrast, Fianna Fáil's 1997 manifesto contained the largest numbers of pledges. The most common type of pledge consists of pledges to expand particular programmes or make changes that would imply increases in government spending. For example, Fianna Fáil promised to end hospital waiting lists, reduce class sizes in schools, and increase the numbers of policy officers. Most pledges are not directly related to pledges made by other parties. Those that are tend to be similar. On a small number of key issues, manifestos provide clear alternatives. These involve pledges that if fulfilled, would mean by definition that pledges of other parties were unfulfilled. For example, in 2002 Fine Gael and Labour pledged to freeze income tax rates. The Progressive Democrats, by contrast, pledged to reduce the top rate from 42 to 40 per cent.

The sources consulted to assess the fulfilment of each pledge depended on the content of the pledge. The relevant criteria for assessing pledge fulfilment are identified in the pledges themselves, since we define a pledge as unequivocal support for a particular action or outcome, specified in enough detail to enable researchers to test whether or not the action or outcome was realized. The pledges led the researchers to examine a range of relevant legislation, ministerial decisions, spending allocations, parliamentary records and official reports. The Legislation Directory of the Irish Statute Book was a useful source for searching for changes to Irish law in line with election pledges.

Each pledge was categorised as fully fulfilled, partly fulfilled or not fulfilled. For example, we judged as fully fulfilled Fianna Fáil's 2002 pledge to establish a training fund of up to $€ 2,500$ per person for unemployed people facing serious barriers to employment. The High Support Process was introduced by the National Training and

\footnotetext{
1 The analysis integrates data from two previous studies (Mansergh 2004; Costello and Thomson 2008). The data from the 2002 manifestos include socioeconomic pledges only, which make up approximately half of all pledges made. There is no significant difference between the rates of fulfilment of socioeconomic pledges and other pledges.

${ }^{2}$ Excludes pledges from 2002.
} 
Employment Authority (FÁS), in 2003. This measure is designed to assist FÁS Employment Officers to better meet the needs of clients who, because of health, literacy or other difficulties experience major barriers to finding employment. In 2006, a total of $€ 2,500$ per person was available under this scheme to resource the relevant interventions such as counselling and supplemental training. ${ }^{3}$ The Progressive Democrats' 2002 pledge to reduce the top rate of income tax from 42 to 40 per cent was only partly fulfilled because the top rate had been reduced to 41 per cent by 2007 . Our tests reveal a high level of inter-coder reliability for this method. A total of 40 pledges were randomly selected and examined by seven researchers. For each pledge, one of the researchers provided the other researchers with the evidence he or she used to evaluate the fulfilment of each pledge without revealing his or her evaluation. Each of the seven researchers then independently categorizes each pledge as 'fully', 'partly', or 'not' fulfilled. On all 40 cases, the majority of the seven researchers agreed on the same coding. On 27 of the 40 pledges, all seven researchers agreed on the same categorization; on eight of the 40 pledges, six researchers agreed; on five pledges, four researchers agreed; and on one pledge four researchers agreed. Across the 40 pledges, we found an average agreement rate of 93 per cent (insert author reference).

Figure 1 summarizes the variation in pledge fulfilment. Over the entire time period, pledges made by parties that entered government office after the elections, which we will refer to as 'governing parties' regardless of whether they were in office before the elections, have a higher rate of pledge fulfilment than pledges made by parties that entered the opposition. Of the 1,783, 801 (44.9 per cent) were at least partly fulfilled and 574 (32.2 per cent) fully fulfilled. Of the 1,898 pledges made by opposition parties over the entire time period, 729 (38.4 per cent) were at least partly fulfilled and 464 (24.5 per cent) fully fulfilled. The difference between governing and opposition parties' pledge fulfilment, although not large, is statistically significant (Chi-2 16.07, $\mathrm{p}=.00$ ). While these aggregate descriptive figures are informative, they are of limited use in disentangling the various factors that influence the likelihood of pledge fulfilment. In the following sections we set out our expectations and test these with a multivariate method.

\footnotetext{
${ }^{3}$ FÁS Annual Report 2003; Dáil Debates 623: 1596, 6 July 2006.
} 
$<$ Figure 1 here $>$

\section{Expectations}

The main assumption behind our expectations is that election pledges are more likely to be fulfilled when the parties that made them hold more governmental power after the elections and when pledges are more responsive to the determinants of public policy. If a governing party is compelled to share power, either with coalition partners or with opposition parties, we expect to observe lower rates of pledge fulfilment than in singleparty governments with secure majorities. Coalition government compels governing parties to moderate their policy demands, either by dropping their demands in particular policy areas in return for control over other policy areas, or by agreeing to compromise outcomes that differ from their election pledges. Governing parties that do not control secure parliamentary majorities may face similar pressures to parties in coalition governments. Policy concessions to one or more opposition parties may be required in exchange for their informal support to get bills passed. The inclusion of opposition parties' pledges in our analysis provides an important benchmark against which to assess the performance of different types of governments in terms of pledge fulfilment.

The fact that parties' election pledges are rarely in direct disagreement with one another may ameliorate the negative effect of coalition government on pledge fulfilment. This feature of party competition, in which parties talk past each other, is one of the main propositions of the saliency theory of party competition that highlights the importance of parties' ownership of different issues (Robertson, 1976; Budge et al., 1987). Nonetheless, even pledges that focus on different aspects of policy and are not in direct disagreement draw on the same pool of government resources, both in terms of public sector finances and policy attention, and therefore compete with each other indirectly.

In contrast to the low level of disagreement, the level of direct agreement among parties is often relatively high. For example, Fianna Fáil and the Progressive Democrats formed a coalition in 2002 on the basis of election manifestos in which approximately 30 per cent of pledges made by each party were in agreement, while only 2 per cent were in direct disagreement. We expect that pledges made by parties in coalition 
government are more likely to be fulfilled when there is consensus among coalition parties. Furthermore, we expect explicit consensus among parties to increase the likelihood of pledge fulfilment, even when it is consensus among government and opposition or among opposition parties. Agreement among parties indicates that the policies are widely supported and are therefore more likely to be implemented by the government.

Within coalitions, negotiations between governing parties are relevant. Several models of coalition formation highlight the importance of proposal power in the formation process in shaping government policy. Coalition formation is modelled as a sequential bargaining process, beginning when a party is selected to make a proposal to form a government and ending when a proposal is accepted by a majority of legislators (Baron 1991; Diermeier and Feddersen 1998; Austen-Smith and Banks 1988; see Laver et al 2011 for a criticism of this approach). These models predict that government policy will be skewed heavily towards the position of the proposer, which is generally the largest party. However, some policy concessions must be offered to the junior coalition partner or partners, to make the offer more attractive than the reversion point (i.e. the position of a caretaker government). While there is limited empirical evidence in support of a formateur advantage in terms of the most visible outcome of negotiations, portfolio allocation (see Laver et al 2011: 288), such an advantage might appear in terms of the policy agreed by the coalition. In the Irish context, there is no formal formatuer party, but conventionally the initiative in government formation goes to the largest party.

Other models of coalition politics also attribute considerable power to the largest party in the coalition. For Huber (1996), the vote of confidence procedure is an important institution. This procedure enables the prime minister to raise the stakes in any vote in parliament by making it a vote of confidence in the government. This severely limits the extent to which junior coalition parties can shape policy outcomes. If a junior party proposed a policy that the senior party disagreed with, the prime minister could reject the proposal in the knowledge that the junior coalition partner will ultimately toe the line in a vote of confidence on the issue, or face an early election. In addition to its power to hold a vote of confidence, recently developed models show how the prime minister's party can shape policy outcomes by reconfiguring the jurisdictions 
of ministerial portfolios (e.g. Thies 2001; Dewan and Hortala-Vallve 2011). Qualitative studies also show how the prime ministership plays a vital role in coordinating the overall direction of policy and setting priorities in modern cabinet governance, and Ireland is often considered to be a country where the power of the prime minister is high in comparative terms (King 1994, O’Leary 1991). These arguments imply that the largest party in a coalition, which in the cases we examine is also always the party of the prime minister, has an advantage in policy formulation and policymaking, and we expect this to give them an advantage in pledge fulfilment.

An alternative view is that government policy in a coalition is not the result of negotiation and compromise between the parties, but rather each party pursues its own agenda in the ministries it controls. In their model of coalition governance, Laver and Shepsle $(1994 ; 1996)$ argue that policymaking in modern states is structured by the division of policy areas into ministerial jurisdictions, whereby parties have little say in policy areas over which they do not receive ministerial control. According to this model, parties will be persuaded to participate in a coalition only if they believe it to be credible in terms of policy. The distribution of ministerial portfolios provides such credibility. ${ }^{4}$ In addition, models of ministerial drift posit that ministers may be tempted to push initiatives that differ from their government's common platform, possibly inflicting costs on some cabinet colleagues and their constituencies (Huber and Shipan 2002: 185; Martin and Vanberg 2004: 15-6). Norms of ministerial responsibility and non-interference in other ministers' portfolios, as well as information asymmetries, discourage other cabinet ministers from detecting this ministerial drift. Following these arguments, we expect that pledges are more likely to be fulfilled if the party that made them went on to hold the relevant ministerial portfolio.

Pledges are more likely to be redeemed when governments have more resources at their disposal, both in terms of material resources and time. In times of economic growth, public finances are under less pressure. Comparative public policy research demonstrates that economic conditions and development are among the most important explanations of variation in policy outputs in addition to the partisan composition of

\footnotetext{
${ }^{4}$ Laver and Shepsle's model also refers specifically to the government agreement between the coalition partners. We do not include a separate variable in the analyses for the coalition agreement since there is reason to believe this is endogenous to some of our key explanatory variables, notably the allocation of ministerial portfolios and agreement among parties.
} 
government (e.g. Huber and Stephens 2001). Previous research found that election pledges are concentrated on electorally salient policy areas such as taxation, health care, education and policing. These are policy areas that effect government revenue and expenditure and are consequently likely to be affected by the general economic situation. We therefore expect that economic growth will increase the likelihood of fulfilment, particularly for pledges that directly affect public finances, such as pledges to expand policy programmes or to cut taxes. In addition, when governments are short in duration, as is the case with several of the governing periods we examine, we anticipate lower levels of pledge fulfilment.

The causes of variation in levels of pledge fulfilment differ for governing and opposition parties. Obviously opposition parties do not vary in the extent of their control over governmental power. However, they do vary in terms of the types of governments they face, and we explore whether opposition parties' pledges are more likely to be fulfilled when they face minority compared to majority governments or coalitions compared single-party governments. Opposition parties' pledges do vary in the extent to which their pledges respond to and are aligned with the determinants of government policies. We examine whether opposition pledges that are in agreement with those made by governing parties are more likely to be fulfilled, and whether opposition pledges that require public expenditure - to expand programmes and cut taxes - are more likely to be fulfilled when economic conditions are favourable. Such expansionary and tax-cut pledges are likely to be popular ones and governing parties are likely to adopt these if economic conditions permit, even if they did not make the pledges themselves.

\section{Analysis}

We apply logistic regression models to examine the factors that affect the likelihood of pledge fulfilment. The dependent variable in each of these analyses is a dichotomous measure indicating whether the pledge is at least partly fulfilled (1) or not fulfilled (0). ${ }^{5}$

\footnotetext{
${ }^{5}$ We also applied multinomial models with a three-category dependent variable. The results were substantively the same, but we prefer the logistic regression since the results are more readily interpretable. Moreover, the reliability of the two-category measure of fulfilment variable was found to be somewhat higher than the three-category measure.
} 
As the factors affecting pledge fulfilment differ for governing and opposition parties, we examine these two groups of pledges separately. We begin by focusing on the factors affecting fulfilment of governing parties' pledges (Table 2). As some of our expectations relate specifically to pledges made by parties in coalition government, we present two logistic regression models in Table 2. Model 1 includes all 1,783 pledges made by governing parties; while Model 2 restricts the analysis to the 1,651 pledges made by parties that entered coalition governments.

\section{$<$ TABLE $2>$}

The first two variables in Model 1 refer to the effect of power sharing and agreement between coalition parties. The variables 'Coalition (with consensus)' and 'Single-party government' are part of a three-category independent variable. The reference group in this three-category variable consists of governing coalition parties' pledges that are not in direct agreement with pledges of their coalition partners. The coefficients for these variables tell us that pledges made by single party governments and by coalition governments where there is a degree of consensus among the coalition partners are significantly more likely to be fulfilled than pledges made by coalition parties without support from their governing partners. The finding regarding coalition party pledges does not take into account whether the party that made the pledge is a senior or junior member of the coalition, an issue to which we return below. It is noteworthy that the effect of 'Coalition (with consensus)' is greater than the effect of 'Single-party government', but the difference in the size of the coefficients is not significant. Recall that all of the single-party governments were Fianna Fáil governments. If we include only the 705 pledges made by Fianna Fáil before it entered government, the coefficient for 'Single-party government' becomes insignificant. This is because Fianna Fáil was always the largest party and held the prime ministership when it participated in coalitions.

The next variable indicates whether the party was in a majority or a minority government. The coefficient for this variable is not statistically significant. So there is no evidence that majority governments are on the whole better able to fulfil their election pledges than parties in minority governments. We also explored whether a 
combination of majority status and coalition status influenced pledge fulfilment, by including an interaction between these variables. However, the interaction was not significant, and we do not report the results here. We noted above that minority governments differ with respect to whether they had made deals with independent parliamentarians, but this does not affect our results. We created a dummy variable for the two governments that did not conclude agreements with independents (the Fine Gael/Labour coalition formed in 1981 and the single-party Fianna Fáil government formed in 1987). When added to Model 1, this dummy variable has a negative sign as expected, but is insignificant $(-.40$; s.e. $.51 ; p=.43)$, while the coefficient for majority status remains insignificant.

Model 2 restricts the analysis to pledges made by parties that entered coalitions after the elections. It also allows us to examine whether the status of a party within the coalition matters for pledge fulfilment. As anticipated, pledges made by parties that hold the prime ministership are significantly more likely to be fulfilled than those made by a junior coalition partner. However, the results do not support the expectation that pledges are more likely to be fulfilled when the party held the relevant ministry.

Figure 2 shows the estimated probability of pledge fulfilment depending on the status of the party within the government and the relationship between government party pledges. The estimates are based on the results in Models 1 and 2, holding other variables in the model at their mean (for continuous variables) or mode (for dichotomous variables). Figure 2 also includes a comparable estimate for opposition party pledges that are not supported by government parties (based on results in Table 3). According to these estimates, pledges made by parties that govern alone have a similar chance of being at least partly fulfilled as pledges made by the prime minister's party in a coalition government where there is no consensus with other coalition parties. Thus, while the results from Model 1 tell us that pledges made by single-party governments are more likely to be fulfilled than pledges made by coalition parties, this is not the case when we compare only parties holding the prime-ministership. ${ }^{6}$ This is an important finding, as it implies that the type of government that forms (coalition or single-party) does not affect the ability of the senior government party to implement its pledges. In

\footnotetext{
${ }^{6}$ The non-significant effect of coalition government is confirmed by running a model which includes only pledges made by parties holding the prime-ministership.
} 
comparison, pledges made by junior government parties are less likely to be fulfilled than pledges made by senior government parties. Figure 2 also highlights the importance of consensus among governing coalition parties. A pledge made by a senior coalition party (i.e. the party of the prime minister) that is supported by a junior coalition party is more likely to be fulfilled than a pledge made by a party that governs alone.

\section{$<$ FIGURE 2>}

The results in Table 2 also show that agreement with opposition parties matters. When a governing party's pledge is similar to a pledge made by an opposition party, the likelihood of fulfilment increases significantly. The magnitude of this effect is similar to that of agreement between coalition parties.

The next set of variables in Model 1 relate to the effect of economic growth on the fulfilment of different types of pledges. The coefficient for the variable 'Growth' is positive and significant, implying that economic growth increases the likelihood of fulfilment for pledges that do not relate to expansionary public policies or tax cuts. The effect of growth is not significantly stronger for expansionary pledges, as shown by the coefficient for the interaction between growth and expansionary pledges. However, we do find that the effect of growth is significantly stronger for tax cut pledges. The effect of economic growth on the likelihood of pledge fulfilment can be best illustrated graphically. The governments examined here experienced very different levels of economic growth, ranging from an average within the government periods of -1.3 per cent to 9.1 per cent. Figure 3 depicts the probability of fulfilment of governing parties' pledges at different levels of economic growth, while other variables in the model are held constant at their mode value. ${ }^{7}$ For non-expansionary, non-tax cut pledges (labelled 'other pledges' in Figure 3), the effect of economic growth is relatively modest. At the lowest level of economic growth, -1.3 per cent, the probability that a pledge is at least partly fulfilled is .27; this increases to .47 at the highest level of economic growth of 9.1 per cent. Expansionary pledges are more likely to be fulfilled at all levels of growth, but

\footnotetext{
${ }^{7}$ Holding other variables at their mode means that Figure 3 depicts estimated effect of fulfilment for pledges made by parties in majority coalition governments that last more than two years, where there is no consensus with other coalition parties or with opposition parties.
} 
growth does not have a significantly stronger effect on the fulfilment of these pledges than it does for other pledges. The most striking finding is in relation to pledges to cut taxes. At low levels of growth, pledges to cut taxes are less likely to be fulfilled than other pledges (the probability of fulfilment is only .17). However, at the highest levels of growth, tax-cut pledges are much more likely to be fulfilled than other pledges (with a probability of .71).

\section{$<$ FIGURE 3 $>$}

Another resource - time - is also relevant to pledge fulfilment. Pledges made by governing parties are significantly less likely to be fulfilled if the government is shortlived. A typical pledge made by a party that goes on to form a short-lived single-party government of less than one yeas has a probability of being at least partly fulfilled of only .11 , compared to .36 for pledges made by single party governments that last longer than one year. ${ }^{8}$

Our multivariate analyses did not include variables that identified pledges to maintain the status quo or pledges to bring about a certain outcome as opposed to taking a certain action that is in principle within the control of government. The reason for omitting these variables is that we have relatively few observations of them. Status quo and outcome pledges each account for less than 2 per cent of our observations. Although the numbers of cases prevent us from examining the effects in our multivariate analyses, we would expect that status quo pledges are more likely to be fulfilled. Indeed, of the 30 status quo pledges made by governing parties, 26 (87 per cent) were at least partly fulfilled, compared to 44 per cent of other types of pledges made by parties that went on to govern. We might also have expected that outcome pledges would be harder to fulfil. However, of the 21 outcome pledges, 16 were at least partly fulfilled. Given the small numbers of observations, we attach little importance to this particular finding. The results of the models presented in Tables 2 and 3 are the same if we exclude these pledges from the analysis.

\footnotetext{
${ }^{8}$ These predicted probabilities were calculated based on Model 1, holding other explanatory variables constant at their means (for continuous variables) or medians (for dichotomous variables). As a robustness test, we also applied models with an additional control for governments that lasted longer than one year, but shorter than three years. This additional variable was insignificant in all of the models.
} 
We now turn to the fulfilment of opposition parties' pledges in Table 3. In line with expectations, opposition parties' pledges are affected mainly by the extent to which they respond to or are congruent with the factors that affect public policies. There is no evidence that the fulfilment of opposition parties' pledges is affected by the type of government they face. By contrast, economic growth has a strong effect on the likelihood of fulfilment for opposition parties' pledges. The effect of economic growth is significantly stronger for both expansionary and tax-cut pledges. Support for opposition parties' pledges by other parties, particularly by governing parties, has a strong positive effect on the fulfilment of opposition parties' pledges. This indicates that many of the opposition parties' pledges that are fulfilled are similar to governing parties' pledges. A notable difference between governing and opposition parties' pledges is that short governments are associated with significantly lower levels of pledge fulfilment for governing parties, but not for opposition parties. This might suggest that the opposition parties' pledges that are fulfilled are ones that are uncontentious, and therefore fulfilled early on in the governing period.

$<$ TABLE 3>

\section{Conclusions}

The main objective of this study was to test whether pledge fulfilment depends on the type of government that forms after the election. The Irish cases allowed us to compare pledge fulfilment in different kinds of governments: coalitions and single-party governments, both with and without parliamentary majorities. In line with the principle of the party mandate, pledges made by parties that entered government office were more likely to be fulfilled than pledges made by parties that entered the opposition after the elections. However, the difference between governing and opposition parties' rates of pledge fulfilment was not always large.

We find that the advantage of holding office depends on the party's position in government more than the type of government that forms. We found no significant difference between rates of pledge fulfilment for governing parties with and without secure parliamentary majorities. The strength of minority governments accords with 
previous research on minority governments in Spain, Sweden and elsewhere, which demonstrates that minority governments find ways of fulfilling their election pledges and bringing about policy change (Artés and Bustos 2008; Naurin 2011; Strøm 1990). One of the ways in which minority governments manage to change policies is to make concessions to opposition parties. For instance, a substantial proportion of the Catalonian Nationalist Party's (CiU) pledges were fulfilled in return for supporting minority Spanish governments in the 1990s (Artés and Bustos 2008). We do not find evidence that opposition parties' pledges were significantly more likely to be fulfilled if they faced minority governments, as in the cases we examine minority governments did not enter into arrangements with opposition parties in return for their support.

In line with previous research, pledges made by parties that govern alone are more likely to be fulfilled than pledges made by parties that are in coalition government (Mansergh and Thomson 2007). However, when we restrict the comparison to parties holding the prime-ministership, we find no significant difference for single-party or coalition governments. This finding challenges the commonly held view that singleparty governments are more conducive to strong programme-to-policy linkages. For the party of the prime minister, a relatively strong link is found to exist between election pledges and subsequent government policy regardless of what type of government forms. In contrast, smaller parties in coalition governments, which are assumed to be in a weaker bargaining position in many models of coalition government, were found to be less successful in fulfilling their pledges.

In coalition governments, the fulfilment of election pledges is likely when the governing parties agree. When coalitions form among parties that are close to each other in policy terms, not only is their electoral mandate clearer (in terms of voters endorsing a particular set of policies), but it is also more likely to be enacted. Indeed, we find that pledges on which prospective coalition partners agree are even more likely to be fulfilled than pledges made by parties that go on to govern alone.

Lijphart's (1999) famous consensus model has been associated with effective performance in several respects. Ireland has an intermediate position on the executiveparties' dimension of consensus democracy (ibid.: 248), reflecting its combination of consensual and majoritarian characteristics. We show that when Irish governments are consensual, whereby they are coalitions of parties that agree with each other, they 
perform at least as well as single-party governments in terms of pledge fulfilment. This key finding is also relevant to other ways of describing differences among democracies. McGann and Latner (2013) argue that policies can be changed more easily in systems of PR-majority rule, of which most of the Irish coalitions are examples, than by singleparty governments.

We found a strong effect of the prevailing economic conditions on pledge fulfilment. All pledges are more likely to be fulfilled when there is strong economic growth and less likely to be fulfilled in times of economic decline. As expected, the effect of economic growth is particularly pronounced for pledges to cut taxes, which were less likely to be fulfilled than other pledges at low levels of growth and more likely to be fulfilled than other pledges at high levels of growth. One interpretation of this finding is that parties make election pledges that are overly optimistic, in that they can only be fulfilled under conditions of strong economic growth. Parties may believe that the short-term electoral reward of making attractive but unrealistic pledges outweighs the negative consequences of not fulfilling them.

\section{References}

APSA (American Political Science Association) (1950) 'Toward a More Responsible Two Party System: A Report of the Committee on Political Parties', American Political Science Review 44: Supplement.

Artés, Joaquín and Antonio Bustos (2008) 'Electoral promises and minority governments: An empirical study', European Journal of Political Research 47: 307333.

Austen-Smith, David and Jeffrey S. Banks (1988) 'Elections, coalitions and legislative outcomes', American Political Science Review 82: 405-22.

Baron, David P. (1991) 'A spatial bargaining theory of government formation in a parliamentary system', American Political Science Review 85: 137-64.

Budge, Ian, David Robertson and Derek Hearl eds. (1987) Ideology, Strategy and Party Change: Spatial Analysis of Post-War Election Programs in Nineteen Democracies. Cambridge: Cambridge University Press.

Budge, Ian and Richard I. Hofferbert (1990) 'Mandates and Policy Outputs: U.S. Party Platforms and Federal Expenditures', American Political Science Review 84 (1): 111-131.

Costello, Rory and Robert Thomson (2008) 'Election Pledges and their Enactment in Coalition Governments: A Comparative Analysis of Ireland', Journal of Elections, Public Opinion and Policy 18 (3): 239-56.

Dewan, Torun and Rafael Hortala-Vallve (2011) 'The Three As of Government Formation: Appointment, Allocation, and Assignment', American Journal of Political Science 55(3): 610-27. 
Diermeier, Daniel and Timothy J. Feddersen (1998) 'Cohesion in legislatures and the vote of confidence procedure', American Political Science Review 92: 611-21.

Downs, Anthony (1957) An Economic Theory of Democracy. New York: Harper

Farrell, Brian and Maurice Manning (1978) 'The Election', in Howard R. Penniman ed. Ireland at the Polls: the Dáil Elections of 1977. Washington D.C.: American Enterprise Institute for Public Policy Research.

Huber, John D. (1996). 'The Impact of Confidence Votes on Legislative Politics in Parliamentary Systems.' American Political Science Review 90:269-82.

Huber, John D. and Charles R. Shipan (2002) Deliberate Discretion? The Institutional Foundations of Bureaucratic Autonomy. Cambridge: Cambridge University Press.

Huber, Evelyne. and Stephens, John D. (2001) Development and Crisis of the Welfare State: Parties and Politics in Global Markets. Chicago: Chicago University Press.

King, Anthony (1994). 'Chief Executives in Western Europe,' in I. Budge and D. McKay (eds), Developing Democracy. London: Sage.

Klingemann, Hans-Dieter, Richard I. Hofferbert and Ian Budge (1994) Parties, Policies, and Democracy. Boulder: Westview Press.

Kostadinova, Petia (2013) 'Democratic performance in post-communist Bulgaria: election pledges and levels of fulfillment, 1997-2005', East European Politics 29(2): 190-207.

Laver, Michael and Kenneth A. Shepsle eds. (1994) Cabinet Ministers and Parliamentary Government. Cambridge: Cambridge University Press.

Laver, Michael and Kenneth A. Shepsle (1996) Making and Breaking Governments: Cabinets and Legislatures in Parliamentary Democracies. New York: Cambridge University Press.

Laver, Michael, Scott de Marchi and Hande Mutlu (2011) 'Negotiation in legislatures over government formation'. Public Choice 147: 285-304.

Lijphart, Arend (1999) Patterns of Democracy: Government Forms and Performance in Thirty-Six Countries. New Haven: Yale University Press.

Mair, Peter and Liam Weeks (2005) 'The party system', in John Coakley and Michael Gallagher (eds.) Politics in the Republic of Ireland, $4^{\text {th }}$ edn. Abingdon: Routledge and PSAI Press.

Mansergh, Lucy E. (2004) Do parties make a difference? The case of governments in Ireland, 1977-1997. Ph.D. Thesis: Trinity College Dublin.

Mansergh, Lucy E. and Robert Thomson (2007) 'Election Pledges, Party Competition and Policymaking', Comparative Politics 39(3): 311-29.

Martin, Lanny W. and Georg Vanberg (2004) 'Policing the Bargain: Coalition Government and Parliamentary Scrutiny', American Journal of Political Science 48(1): 13-27.

McGann, Anthony J. and Michael Latner (2013) 'The Calculus of Consensus Democracy: Rethinking Patterns of Democracy Without Veto Players', Comparative Political Studies 46(7): 823-50.

Naurin, Elin (2011) Election promises, party behaviour and voter perceptions. Basingstoke: Palgrave Macmillan.

Naurin, Elin (2014). 'Is a Promise a Promise? Election Pledge Fulfilment in Comparative Perspective Using Sweden as an Example', West European Politics 37(5): 1046-64.

O'Leary, Brendan (1991). 'An Taoiseach: The Irish Prime Minister', in G.W.Jones (ed.), West European Prime Ministers. London: Frank Cass. 
Peters, Guy B., R.A.W. Rhodes and Vincent Wright eds. (2000) Administering the Summit: Administration of the Core Executive in Developed Countries. Houndmills: Macmillan.

Pomper Gerald M. and Susan S. Lederman (1980) Elections in America: Control and Influence in Democratic Politics, 2nd ed. New York: Longman.

Rallings, Colin (1987) 'The influence of election programs: Britain and Canada 19451979', in Ian Budge, David Robertson and Derek Hearl. (eds.) Ideology, Strategy and Party Change: Spatial Analysis of Post-War Election Programs in Nineteen Democracies, pp. 1-15. Cambridge: Cambridge University Press.

Robertson, David (1976) A Theory of Party Competition. London: Wiley.

Royed, Terry J. (1996) 'Testing the Mandate Model in Britain and the United States: Evidence from the Reagan and Thatcher Eras', British Journal of Political Science 26: 45-80.

Sinnott, Richard (2005) 'The rules of the electoral game', in John Coakley and Michael Gallagher (eds) Politics in the Republic of Ireland, $4^{\text {th }}$ edn, pp.105-134. Abingdon: Routledge and PSAI Press.

Strøm, Kaare (1990) Minority Government and Majority Rule. Cambridge: Cambridge University Press.

Thies, Michael. F. (2001) 'Keeping Tabs on Partners: The Logic of Delegation in Coalition Governments', American Journal of Political Science 45(3): 580-98.

Thomson, Robert (2001) 'The programme to policy linkage: The fulfilment of election pledge on socio-economic policy in the Netherlands, 1986-1998' European Journal of Political Research 40: 171-197.

Weeks, Liam. 2010. Parties and the party system. In John Coakley and Michael Gallagher (eds) Politics in the Republic of Ireland, $5^{\text {th }}$ edn. Abingdon: Routledge and PSAI Press, 137-67. 
Figures and tables

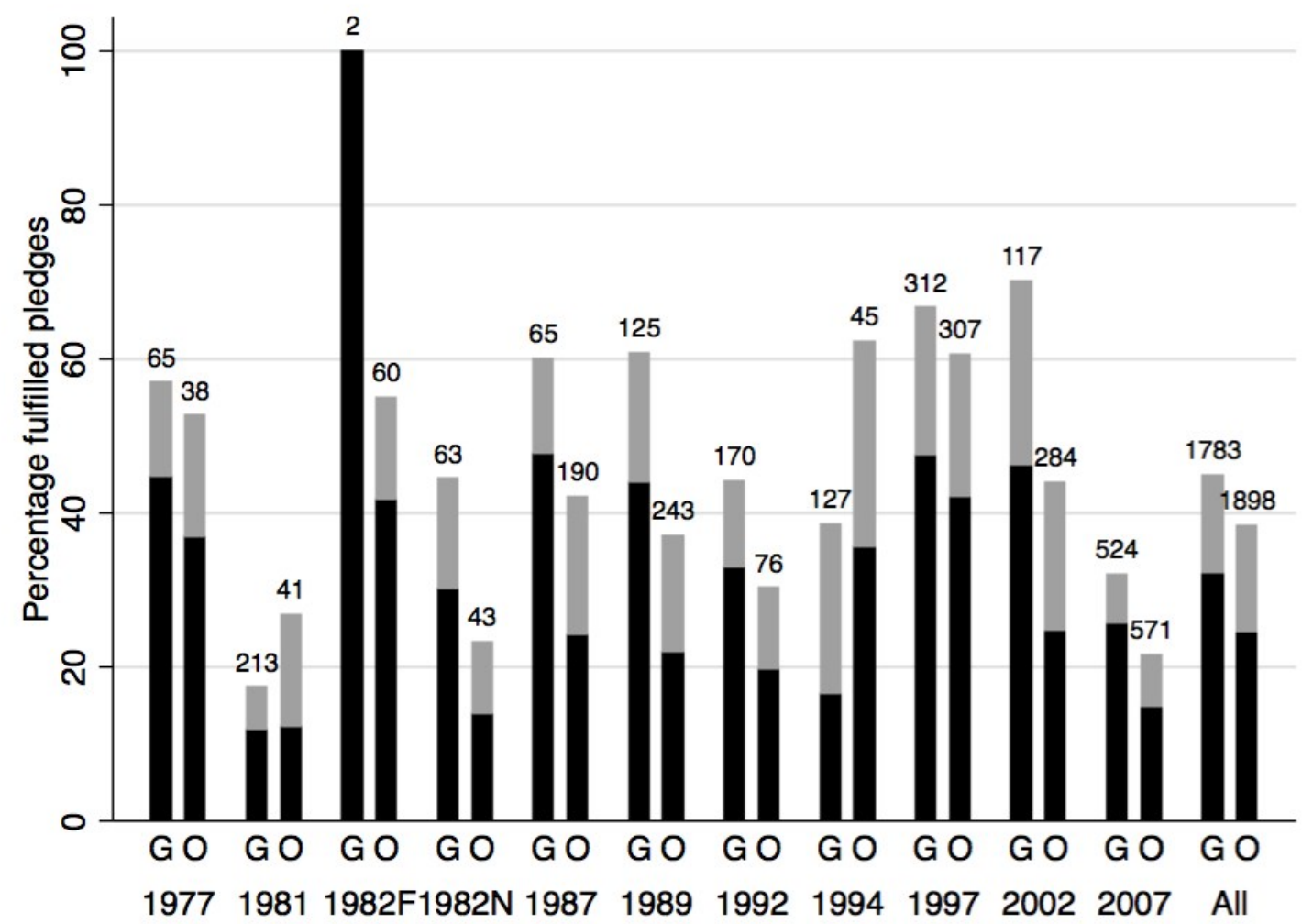

Figure 1. Pledge fulfilment in Ireland, 1977-2011.

Note: Black bars refer to the percentages of fully-fulfilled pledges; grey bars to partly-fulfilled pledges. G. stands for 'governing parties'; O. for 'opposition parties'. 1982F refers to the February 1982 election and $1982 \mathrm{~N}$ to the November 1982 election. The numbers refer to the total number of tested pledges made by governing and opposition parties. 


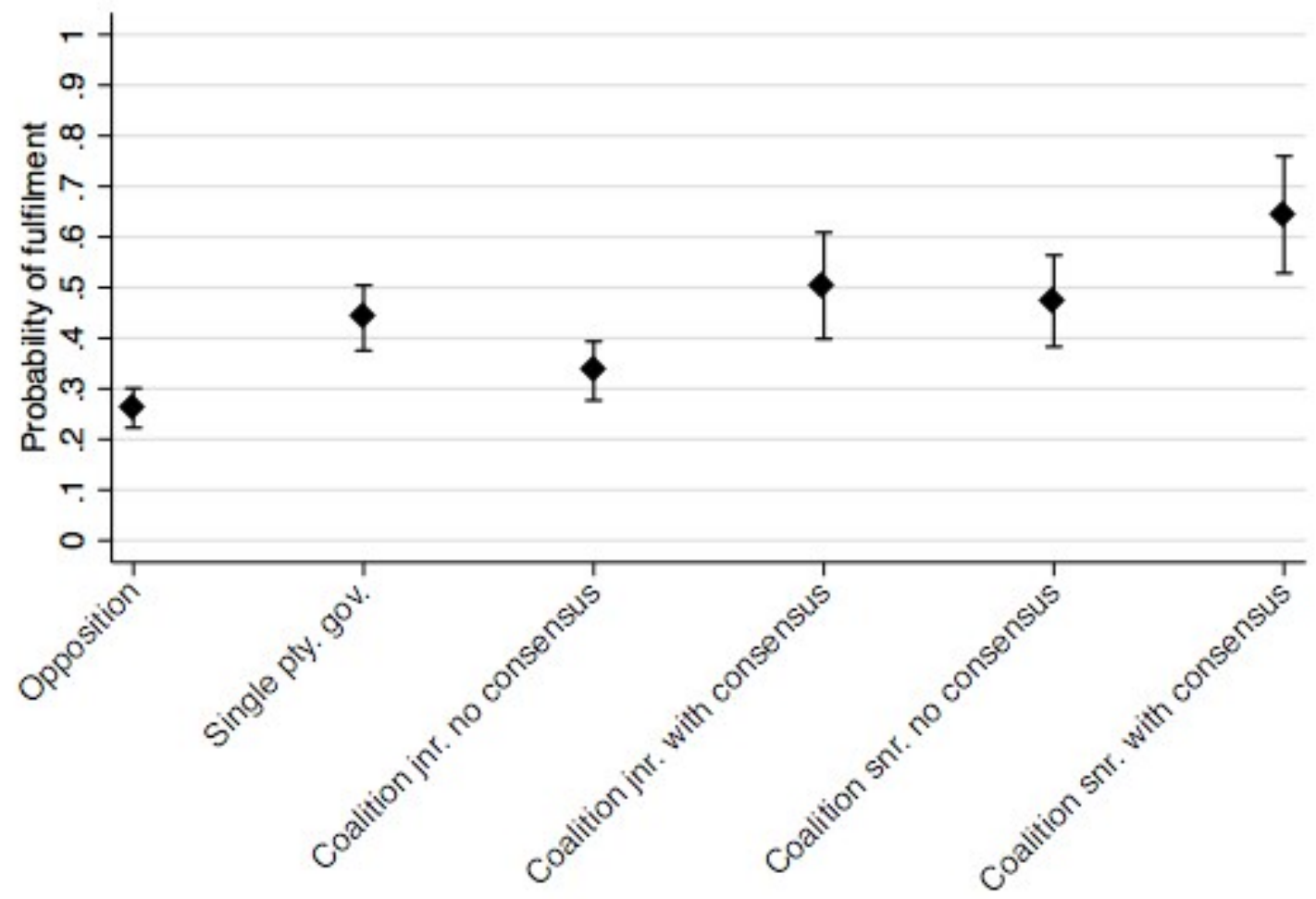

Figure 2. The effect of party's government status on pledge fulfilment

Probability of fulfilment for opposition parties estimated from the model in Table 3; for parties in singleparty governments from Model 1 in Table 2; and for parties in coalition governments from Model 2 in Table 2. Other explanatory variables held at their means/modes. 'Coalition' indicates a party in coalition government. 'Jnr' indicates a coalition party that did not hold the prime ministership. 'Snr' indicates a coalition party that held the prime ministership. 'Consensus' indicates that the pledge was supported by another government party. 


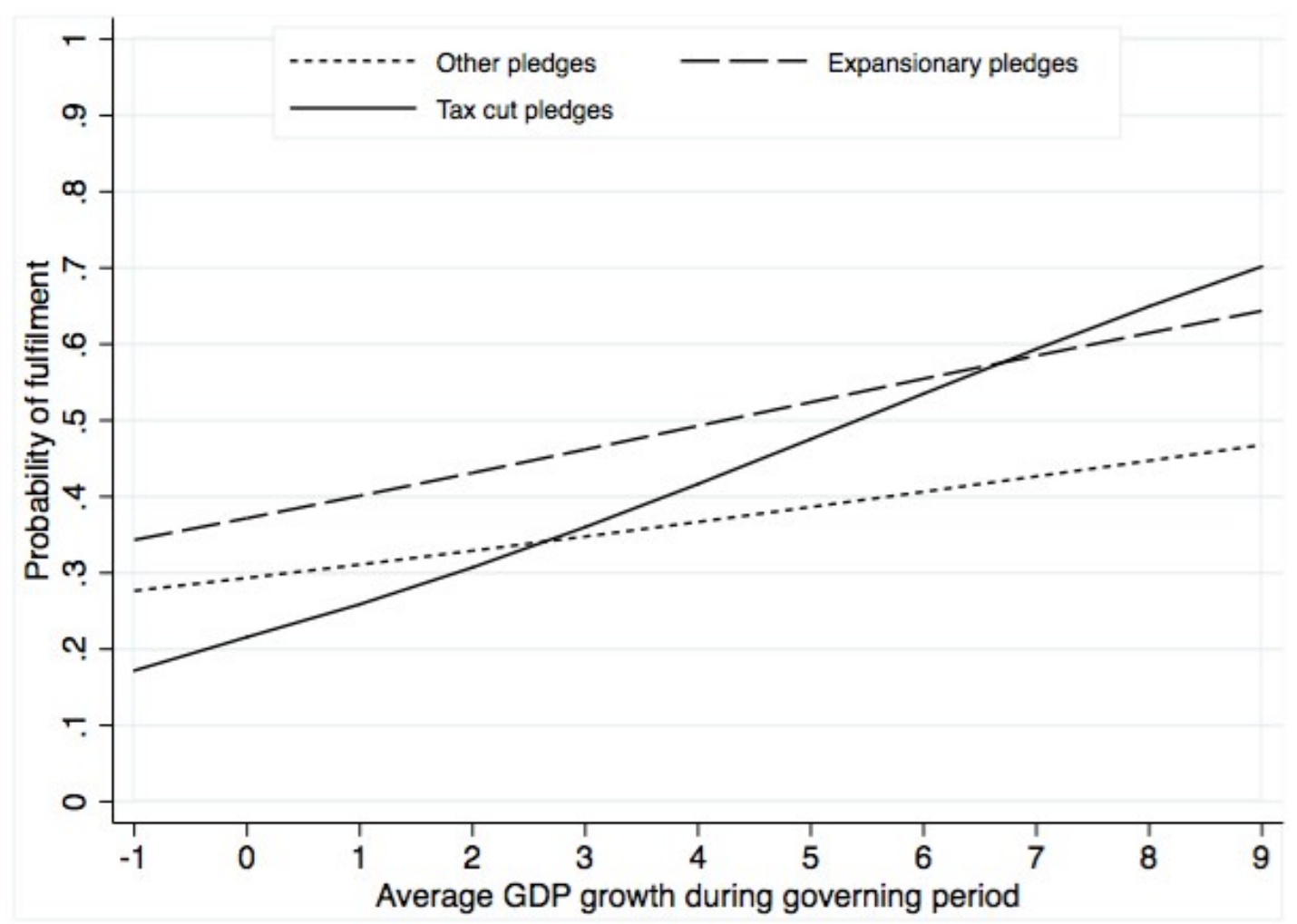

Figure 3. The effect of GDP growth on the fulfilment of governing parties' pledges

Estimated with Model 1 in Table 2, holding the values of other explanatory variables at their modes. 
Table 1. The eleven Irish governments included in the study

\begin{tabular}{lll}
\hline $\begin{array}{l}\text { Parliamentary } \\
\text { support }\end{array}$ & Single-party & Coalition \\
\hline Minority & 82: Fianna Fáil (9 months) & 81-82: Fine Gael/Labour (8 months) \\
& 87-89: Fianna Fáil & 97-02: Fianna Fáil/ Progressive Democrats \\
Majority & 77-81: Fianna Fáil & 82-87: Fine Gael/Labour \\
& & 92-94: Fianna Fáil/ Progressive Democrats \\
& & 94-97: Fine Gael//Labour/Democratic Left \\
& & 02-07: Fianna Fáil/ Progressive Democrats \\
& & 07-11: Fianna Fáil/ Greens/ Progressive Democrats $\dagger$
\end{tabular}

$\dagger$ Note The 20017-11 coalition lost its majority when the Progressive Democrats disbanded in 2009, but the PD leader, Mary Harney, retained her cabinet post and supported the government as an independent. 


\begin{tabular}{|c|c|c|c|c|}
\hline & \multicolumn{2}{|c|}{$\begin{array}{c}\text { Model 1: } \\
\text { All government party } \\
\text { pledges }\end{array}$} & \multicolumn{2}{|c|}{$\begin{array}{c}\text { Model 2: } \\
\text { Coalition party } \\
\text { pledges }\end{array}$} \\
\hline & b (s.e.) & $\mathrm{p}$ & b (s.e.) & $\mathrm{p}$ \\
\hline \multicolumn{5}{|l|}{ Government type } \\
\hline \multicolumn{5}{|l|}{$\begin{array}{l}\text { Power sharing and agreement } \\
\text { between governing parties } \\
\text { (reference group: coalition } \\
\text { parties, no agreement) }\end{array}$} \\
\hline Coalition (with consensus) & $.65(.16)$ & .00 & $.70(.17)$ & .00 \\
\hline Single-party gov't & $.33(.12)$ & .00 & - & - \\
\hline Majority government & $-.24(.29)$ & .39 & $.04(.32)$ & .90 \\
\hline \multicolumn{5}{|l|}{ Position of party in coalition } \\
\hline Prime ministership & - & & $.58(.17)$ & .00 \\
\hline Relevant ministry & - & & $.13(.16)$ & .43 \\
\hline \multicolumn{5}{|l|}{$\begin{array}{l}\text { Economic conditions and type of } \\
\text { pledge }\end{array}$} \\
\hline Growth & $.08(.04)$ & .03 & $.09(.04)$ & .01 \\
\hline Expansionary pledge & $.35(.10)$ & .00 & $.36(.10)$ & .00 \\
\hline Growth $\times$ expansionary pledge & $.04(.03)$ & .16 & $.03(.03)$ & .28 \\
\hline Tax cut pledge & $-.41(.29)$ & .15 & $-.51(.29)$ & .07 \\
\hline Growth $\times$ tax cut pledge & $.15(.05)$ & .00 & $.15(.05)$ & .00 \\
\hline $\begin{array}{l}\text { Short duration of government } \\
(1=\text { less than } 1 \text { year; } 0=\text { longer) }\end{array}$ & $-1.56(.40)$ & .00 & $-1.51(.28)$ & .00 \\
\hline Opposition support & $.63(.18)$ & .00 & $.61(.20)$ & .00 \\
\hline Constant & $-.63(.31)$ & .04 & $-1.20(.40)$ & .00 \\
\hline Chi2 (p) & $314.77(.00)$ & & 664.32 & \\
\hline Log pseudolikelihood & -1091.24 & & -986. & \\
\hline $\mathrm{n}$ & 1783 & & 165 & \\
\hline
\end{tabular}


Table 3. Factors affecting fulfilment of opposition party pledges

\begin{tabular}{lcc}
\hline & $\mathrm{b}(\mathrm{s} . \mathrm{e})$. & $\mathrm{p}$ \\
\hline Type of government faced & $.27(.21)$ & .20 \\
Single-party & $-.16(.21)$ & .44 \\
Majority & & \\
& & .00 \\
Economic conditions and type of pledge & $.10(.03)$ & .86 \\
$\quad$ Growth & $.03(.16)$ & .00 \\
Expansionary pledge & $.10(.03)$ & .43 \\
Growth $\times$ expansionary & $-.46(.58)$ & .06 \\
Tax cut pledge & $.15(.08)$ & .78 \\
Growth $\times$ tax cut & $.10(.36)$ & .05 \\
& & .00 \\
Short duration of government & $.30(.15)$ & \\
(1=less than 1 year; $0=$ longer) & $.84(.14)$ & .00 \\
Opposition support & $-1.25(.28)$ \\
Government support & $399.07(.00)$ \\
Constant & -1137.18 \\
Chi2 (p) & 1898 \\
Log pseudolikelihood \\
$\mathrm{n}$
\end{tabular}

